book. The Comparator Test Papers provide a higher degree of accuracy, to $0 \cdot 3 \mathrm{pH}$, inside narrower ranges, in four kinds from $p H 3.6$ to $p H 10$, the colours being again printed inside the cover. The papers can be dipped into the solution, or the latter applied by a glass rod. We have tested both kinds of papers with buffer solutions and have found the colour changes to be as stated. They should be very useful to chemists, biologists, physicians, and workers in various industries, when a rapid and reasonably accurate method of measuring $p \mathrm{H}$ is desired. Messrs. Johnson also make a wide range of other test papers and supply a special grade of litmus in the form of granules free from the usual fillings of gypsum or calcium carbonate and requiring only extraction with water to produce an indicator solution. The firm is investigating supplies of lichens from various parts of the world in attempts to produce a high-quality litmus. It is interesting to note that the firm was established so long ago as 1743 .

\section{Plant Health in the Argentine}

Prof. J. B. Marchionatto has prepared a study of plant health in the Argentine from the colonial period in 1810 down to 1943. (Fac. Agron. y Vet., Univ. Buenos Aires). It is divided into four parts, the first of which is almost entirely historical, giving a description of the development of plant life and also a short account of the work of some of the outstanding men who have devoted their time to this subject. The second part describes the conditions in the Department of Agriculture when Prof. Marchionatto took charge of the Laboratory of Plant Pathology. It also includes a survey of the work that was carried out between 1923 and 1932, when the Division of Phytopathology was formed; Pref. Marchionatto's small laboratory was moved to the new Division, and in 1935 was transferred to the Bureau of Plant Health. Part 3 deals with the organisation of the official services in connexion with the health of plants, the discharge of fiscal duties, the sanitary examination and control of the Department of Agriculture, etc. Part 4 contains an account of progress in the investigation of diseases of plants, and the work and results in the regional laboratories are described.

\section{Government Museum, Trivandrum, Travancore}

THE administration report of the Government Museum at Trivandrum for the year 1944-45 is prefaced by statements which imply an unusually strong official confidence in a museum's service. It is somewhat startling to read, for example, that this Museum "has . . . enlarged the minds of the visitors by multiplying their interests, trained their tastes and tended to develop in them an appreciation of the beautiful". Nevertheless, the attendance figures brought forward to support these and other claims certainly indicate a service which is of strong appeal to the people. It is noteworthy that during the year the smallest number of visitors to the Museum on any one day was 589 , while the largest number was 12,947. Casts (made by a member of the staff) of sculptures in the temple at Suchindrum are now on exhibition in the Museum; they are described in detail on p. 2 of the report. Dr. J. H. Cousins has prepared a new guide to the Art Museum, which is issued free to visitors, and a small catalogue of the metal images is also available.

\section{Recent Earthquakes}

DuRINg September, nineteen strong earthquakes were registered by the observatories in Switzerland. The earthquake of September 10 had its epicentre near V. Camonica in the Italian Alps; that of September 12 in the Shansi province of China, and those of September 29 and 30 in the Solomon Islands and Peru respectively. During October, fifteen strong earthquakes were registered in Switzerland. That of October 23 occurred in the Karnische Alps near Trieste, and that of October 30 in the Aleutian Islands. During the first half of November, there were six strong earthquakes in various parts of the globe. That of November 1 occurred in the Aleutian Islands and that of November 2 was destructive in the Uzbeck and Kirghiz districts of the U.S.S.R. The earthquake of November 3 had its epicentre approximately on the equator at long. $17^{\circ} \mathrm{W}$., whereas that of November 4 had its epicentre near lat. $40^{\circ} \mathrm{W}$., long. $53.5^{\circ} \mathrm{E}$. near the Caspian Sea. Epicentres of the above earthquakes in November have been obtained, using instrumental reports from observatories, by the U.S. Coast and Geodetic Survey, in co-operation with Science Service and the Jesuit Seismological Association, as well as by the International Seismological Office at Strasbourg. The U.S. Coast and Geodetic Survey has also determined the epicentres of the earthquakes of November 10 and 12. The former was destructive near Sihuas, about 225 miles north of Lima in Peru, and the latter occurred near lat. $21^{\circ} \mathrm{S}$., long. $173^{\circ} \mathrm{W}$.

\section{Economic Reconstruction in Great Britain}

THE Council of the Royal Society of Arts has decided to devote eight of the remaining ordinary meetings during the present session to a series of eight lectures, dealing with various aspects of economic reconstruction in Great Britain. The lectures will be given at the Society's House in John Adam Street, Adelphi, London, at 5 o'clock, on Wednesdays, the first being on January 15, and will be followed in all cases by an open discussion. The topies to be dealt with include the relation of Britain to the world trade situation, scientific approach to labour problems, materials, finance, craftsmanship, production, distribution and economies.

\section{Announcements}

Mr. W. C. F. Hessenberg, chief officer of the Liaison Department of the British Non-Ferrous Metals Research Association, has been appointed head of the Mechanical Working Division of the British Iron and Steel Research Association, and will take up his new post in a few months time.

IT is announced by British Drug Houses, Ltd., that Dr. F. Hartley, Dr. C. Ockrent, Mr. H. G. Rolfe and Mr. G. F. Williams have joined the board of the company. Dr. F. H. Carr and Mr. R. R. Bennett have retired from active participation in executive work, but Dr. Carr will continue as chairman of the company and Mr. Bennett as director.

Erratum.-Miss Mariam George, writing with reference to the communication "Synergic Action of Penicillin and Bacteriostatic Dyes" (Nature, November 16,1946 , p. 709 ), states that in the two tables, the minimum inhibiting concentration of dyes should be $\frac{1}{1.75} \times 10^{-6}, \frac{1}{2} \times 10^{-4}$, etc., instead of $1.75 \times 10^{-6}, 2 \times 10^{-4}$, etc. 